\title{
Spatial investigation of soil penetration resistance and its impacts on cultivation of 'BRS Princesa' banana
}

\author{
Investigação espacial da resistência do solo à penetração e seus impactos em cultivo de banana 'BRS \\ Princesa' \\ Investigación espacial de la resistencia del suelo a la penetración y sus impactos en el cultivo de \\ banano 'BRS Princesa'
}

Received: 05/11/2021 | Reviewed: 05/17/2021 | Accept: 05/18/2021 | Published: 06/06/2021

Eudocio Rafael Otavio da Silva ORCID: https://orcid.org/0000-0002-5609-3184 Federal Rural University of Rio de Janeiro, Brazil E-mail: eudociootavio@hotmail.com

Marcos Gervasio Pereira

ORCID: https://orcid.org/0000-0002-1402-3612 Federal Rural University of Rio de Janeiro, Brazil E-mail: mgervasiopereira01@gmail.com

Murilo Machado de Barros ORCID: https://orcid.org/0000-0003-0378-4800 Federal Rural University of Rio de Janeiro, Brazil E-mail: egmurilo@yahoo.com.br

Gabriele Oliveira Silva

ORCID: https://orcid.org/0000-0003-4734-0099 Federal Rural University of Rio de Janeiro, Brazil E-mail: ggabriele.oliveira@gmail.com

Patrícia Oliveira Tavares

ORCID: https://orcid.org/0000-0003-1134-2105 Federal Rural University of Rio de Janeiro, Brazil

E-mail: patriciatavares_2014@hotmail.com

André Felipe de Sousa Vaz

ORCID: https://orcid.org/0000-0002-2750-1660 Federal Rural University of Rio de Janeiro, Brazil E-mail: afsagro@hotmail.com

\begin{abstract}
The present study aimed to investigate the spatial variability of soil penetration resistance (SPR) in cultivation areas of 'BRS Princesa' banana, to evaluate its effects on the chemical and physical attributes of the soil and to indicate localized management. The experiment was carried out in an area of cultivation 'BRS Princesa' banana, in which 60 georeferenced points were recorded. SPR was measured from the cone index to $0.40 \mathrm{~m}$ depth using an impact penetrometer. Disturbed samples were collected at depths of 0-0.05, 0.05-0.10, 0.10-0.20 and 0.20-0.40 m and the soil attributes $\mathrm{pH}, \mathrm{Ca}, \mathrm{Mg}, \mathrm{Al}, \mathrm{Na}, \mathrm{K}, \mathrm{P}, \mathrm{H}+\mathrm{Al}, \mathrm{SB}, \mathrm{T}$ Value, V\%, total sand, total clay, silt, TOC, POC, MAOC and gravimetric moisture were determined. The data were subjected to descriptive statistics, Pearson's linear correlation and geostatistical analysis. SPR values in subsurface suggest greater compaction in subsurface and the significant correlations with soil attributes indicate losses for banana plants, so localized management should be carried out. It was found that $46.7 \%$ of the total area of the banana plantation does not need to be decompacted, and localized subsoiling at a varying depth is indicated in the other regions.
\end{abstract}

Keywords: Banana farming; Compaction; Localized subsoiling.

\section{Resumo}

O presente estudo teve como objetivo investigar a variabilidade espacial da resistência do solo a penetração (RSP) em áreas de cultivo da banana 'BRS Princesa', avaliar seus efeitos nos atributos químicos e físicos do solo e indicar manejo localizado. O experimento foi realizado na UFRRJ, Seropédica-RJ, em área de cultivo da banana 'BRS Princesa', no qual realizou-se a coleta de 60 pontos georreferenciados. A RSP foi mensurada a partir do índice de cone até a profundidade de $0,40 \mathrm{~m}$ utilizando-se um penetrômetro de impacto. Realizou-se a coleta de amostras de terra deformadas nas profundidades de 0-0,05, 0,05-0,10, 0,10-0,20 e 0,20-0,40 m e obtidos os atributos do solo $\mathrm{pH}, \mathrm{Ca}, \mathrm{Mg}$, Al, Na, K, P, H + Al, SB, Valor T, V\%, areia e argila total, silte, COT, COp, COam e umidade gravimétrica. Os dados foram submetidos a estatística descritiva, correlação linear de Pearson e análise geoestatística. Os valores da RSP em 
profundidade sugerem maior compactação em subsuperfície e as correlações significativas com os atributos do solo indicam prejuízos as bananeiras, devendo ser realizados manejos localizados. Verificou-se que 46,7\% da área total do bananal não necessita ser descompactado, sendo indicada a subsolagem localizada em profundidade variada nas demais regiões.

Palavras-chave: Bananicultura; Compactação; Subsolagem localizada.

\section{Resumen}

El presente estudio tuvo como objetivo investigar la variabilidad espacial de la resistencia del suelo a la penetración (RSP) en áreas de cultivo de banano 'BRS Princesa', evaluar sus efectos sobre los atributos químicos y físicos del suelo e indicar manejo localizado. El experimento se llevó a cabo en la UFRRJ, Seropédica-RJ, en un área de cultivo de banano 'BRS Princesa', en la que se recolectaron 60 puntos georreferenciados. La RSP se midió desde el índice del cono hasta una profundidad de 0,40 m utilizando un penetrómetro de impacto. Se recolectaron muestras de suelo deformado a profundidades de 0-0.05, 0.05-0.10, 0.10-0.20 y 0.20-0.40 my se obtuvieron los atributos de pH del suelo. Ca, Mg, $\mathrm{Al}, \mathrm{Na}, \mathrm{K}, \mathrm{P}, \mathrm{H}+\mathrm{Al}, \mathrm{SB}$, T valor, V\%, arena y arcilla total, limo, COT, COp, COam y humedad gravimétrica. Los datos se sometieron a estadística descriptiva, correlación lineal de Pearson y análisis geoestadístico. Los valores de RSP en profundidad sugieren una mayor compactación en el subsuelo y las correlaciones significativas con los atributos del suelo indican pérdidas a los bananos, por lo que se debe realizar un manejo localizado. Se encontró que el $46,7 \%$ del área total de la plantación bananera no necesita ser desempaquetada, y se indica el subsuelo ubicado a profundidad variable en las otras regiones.

Palabras clave: Cultivo de banano; Compactación; Subsuelo localizado.

\section{Introduction}

Cultivated in approximately 135 countries, banana is one of the highlights of the global fruit growing, generating about US\$1.2 billion a year in exports (Food and Agriculture Organization - FAO, 2021). It is one of the agricultural sectors with the highest growth projection in the coming years (FAO, 2020). In 2018, there were about 5,728,680 ha in harvested area worldwide, $115,737,861 \mathrm{t}$ in quantity produced and a yield of 20, $20 \mathrm{t}$ ha-1 (FAO, 2018).

Brazil is the fifth largest producer in the world with about 7,113,594 tons in 2019 (Brazilian Statistics Institute - IBGE, 2019), being the fourth country with the largest harvested area in the world. In this scenario, 'BRS Princesa' banana stands out, a variety that is resistant to yellow and black sigatokas and Fusarium wilt, requires a smaller irrigation depth and has greater resistance to lower temperatures compared to other varieties (Borges \& Cordeiro, 2021).

However, for these plants to express their maximum production potential, soil quality must be assessed, since the impediment to the development of banana roots due to soil physical conditions has been indicated as one of the main factors for low yield in banana plantations (Villarreal-Núñez et al., 2013). Banana roots are sensitive to compaction and high penetration resistance (Miotti et al., 2013; Olivares et al., 2020) and, if cultivated under these conditions, there may be a significant decrease in the total number of leaves, average and total leaf area, pseudostem diameter and height of the succession plant (VillarrealNúñez et al., 2013).

Soil penetration resistance (SPR) is one of the main indicators of soil physical quality (Tiecher, 2016; Cortez et al., 2020). Studies evaluating the spatial variability of SPR and its effects on attributes of soils cultivated with cereals, grasses and legumes are easily found in the literature, but there are few studies conducted in orchards, especially in banana plantations. Approaches using geostatistical procedures and spatial inference of soil attributes suggest localized managements that bring benefits to banana growers, hence reducing the costs with mechanized soil tillage operations in areas where banana plantations will be implemented or renewed.

The objective of this study was to investigate the spatial variability of soil penetration resistance in cultivation areas of 'BRS Princesa' banana, to evaluate its effects on soil attributes that may be interfering in the development of the banana plantation and to indicate localized management with subsoiling at varying depth. 


\section{Methodology}

\subsection{Study area description and history}

The experiment was carried out at the Federal Rural University of Rio de Janeiro (UFRRJ), Seropédica - RJ, Brazil, in cultivation areas of 'BRS Princesa' banana. The climate of the region is tropical humid, Aw, according to Köppen's classification, with average annual temperature of $24{ }^{\circ} \mathrm{C}$ and average precipitation of $1260 \mathrm{~mm}$. The soil was classified as Ultisol (Argissolo Amarelo) (Santos et al., 2018), located in an area of gently undulating relief, at an altitude of $27 \mathrm{~m}$.

The banana plantation is $1829.8 \mathrm{~m} 2$ and was implemented in August 2014 with different planting densities throughout the experimental area (Lanza et al., 2017). Soil tillage was performed with one plowing, two harrowing operations, one subsoiling at $50 \mathrm{~cm}$ depth and furrowing.

\subsection{Generation of georeferenced database}

Along the rows and interrows of the banana plantation, a sampling grid consisting of 60 georeferenced points was generated, with 3 subsamples, in total of 180 samples and constituting a systematic sampling with semi-regular grid (Figure 1).

Figure 1. Experimental area located in the municipality of Seropédica-RJ, Brazil, and distribution of the sampling grid for SPR evaluation in the banana plantation.

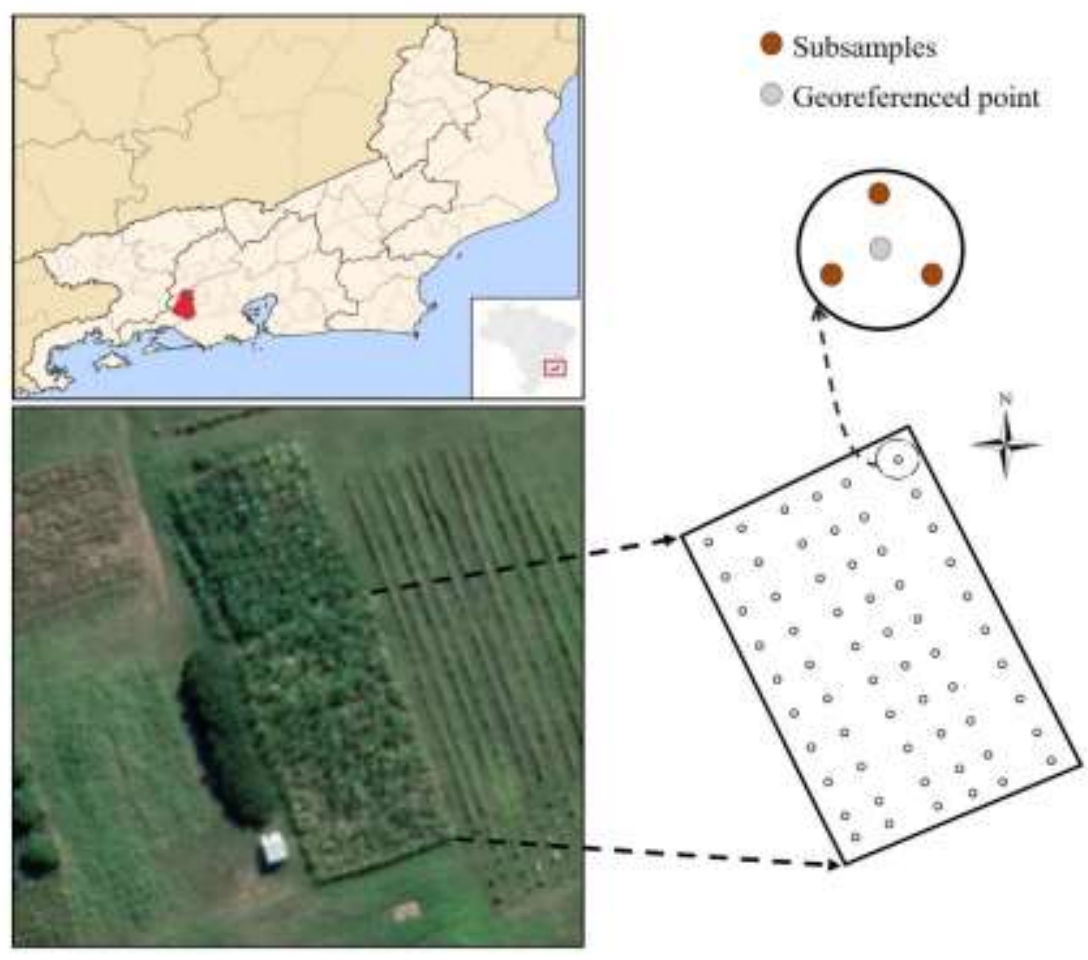

Source: Authors.

All points related to sampling sites were georeferenced and recorded using Leica Geosystems' Total Station, TPS300 Basic Series, in the two-dimensional cartesian coordinates UTM for zone 23S.

SPR was obtained from the cone index (CI) using an impact penetrometer, model IAA/Planalsucar-Stolf (Stolf et al., 1983) with a cone angle of $30^{\circ}$, and measured up to a depth of $0.40 \mathrm{~m}$. The study was conducted in 2019 , a winter season characterized as dry and with low rainfall (Figure 2). 
Figure 2. Maximum, mean and minimum temperatures $\left({ }^{\circ} \mathrm{C}\right)$ (a) and rainfall data (b) for the region of Seropédica-RJ, Brazil, in July 2019, experimental and SPR evaluation period. Red arrow indicates the sampling period and obtaining of the variables under stud.
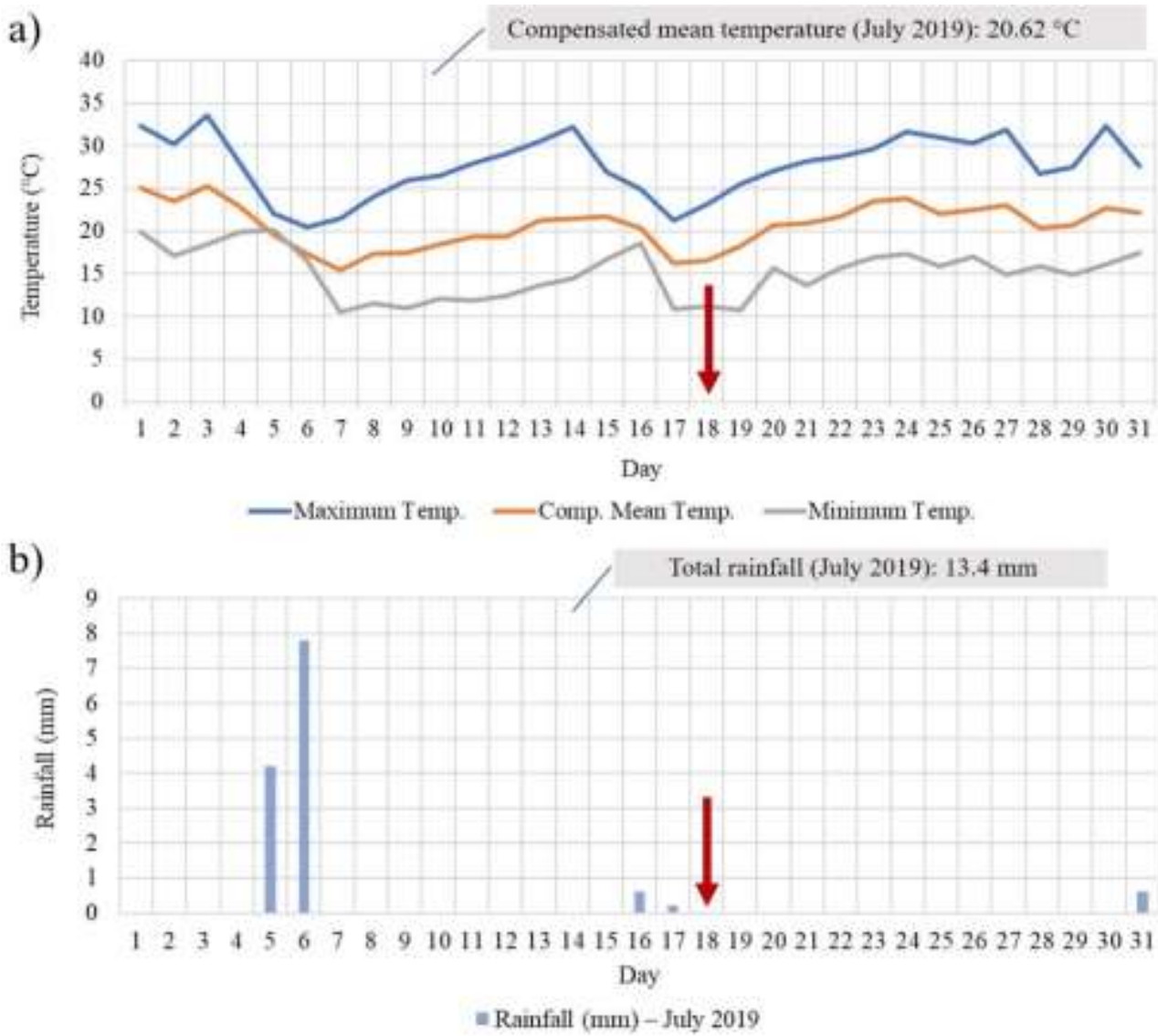

Source: Authors.

The current moisture was evaluated (Teixeira et al., 2017) and the mean values were equal to 10.8, 9.6, 11.4 and 12.0\% for the layers of $0-0.05,0.05-0.10,0.10-0.20$ and $0.20-0.40 \mathrm{~m}$, respectively.

Soil samples were collected in the same sampling grid where SPR evaluations were performed. Soil samples were collected at depths of 0.0-0.05, 0.05-0.10, 0.10-0.20 and 0.20-0.40 m and analyzed for the following parameters: $\mathrm{pH}, \mathrm{Ca}, \mathrm{Mg}$, $\mathrm{Al}, \mathrm{H}+\mathrm{Al}, \mathrm{Na}, \mathrm{K}, \mathrm{P}$, sum of exchangeable bases (SB), cation exchange capacity ( $\mathrm{T}$ value), base saturation (V\%), particle-size fractions of total sand, total clay and silt. All analyses were performed according to Teixeira et al. (2017).

Total organic carbon (TOC) was determined according to Yeomans and Bremner (1988) and particle-size fractionation of SOM in the surface layers (0-0.05, 0.05-0.10 and 0.10-0.20 m) according to Cambardella and Elliott (1992), obtaining particulate organic carbon (POC) and mineral-associated organic carbon (MAOC). The mean values of soil attributes in the banana plantation area are shown in Table 1. 
Table 1. Mean values of soil attributes obtained from the sampling grid in the banana plantation.

\begin{tabular}{|c|c|c|c|c|}
\hline \multirow{2}{*}{ Variable } & \multicolumn{4}{|c|}{ Depth } \\
\hline & $0.0-0.05 \mathrm{~m}$ & 0.05-0.10 m & $0.10-0.20 \mathrm{~m}$ & $0.20-0.40 \mathrm{~m}$ \\
\hline $\mathrm{pH}$ & 6.48 & 5.92 & 5.25 & 5.90 \\
\hline $\mathrm{Ca}\left(\mathrm{cmol}_{\mathrm{c}} \mathrm{kg}^{-1}\right)$ & 2.67 & 2.06 & 1.87 & 1.84 \\
\hline $\mathrm{Mg}\left(\mathrm{cmol}_{\mathrm{c}} \mathrm{kg}^{-1}\right)$ & 4.25 & 4.50 & 2.22 & 2.81 \\
\hline $\mathrm{Al}\left(\mathrm{cmol}_{\mathrm{c}} \mathrm{kg}^{-1}\right)$ & 0.00 & 0.00 & 0.07 & 0.09 \\
\hline $\mathrm{H}+\mathrm{Al}\left(\mathrm{cmol}_{\mathrm{c}} \mathrm{kg}^{-1}\right)$ & 1.61 & 2.15 & 2.58 & 3.19 \\
\hline $\mathrm{Na}\left(\mathrm{cmol}_{\mathrm{c}} \mathrm{dm}^{-3}\right)$ & 0.006 & 0.002 & 0.002 & 0.007 \\
\hline $\mathrm{K}\left(\mathrm{cmol}_{\mathrm{c}} \mathrm{dm}^{-3}\right)$ & 0.028 & 0.008 & 0.006 & 0.006 \\
\hline $\mathrm{P}\left(\mathrm{mg} \mathrm{L}^{-1}\right)$ & 24.99 & 13.94 & 15.50 & 6.67 \\
\hline $\mathrm{SB}\left(\mathrm{cmol}_{\mathrm{c}} \mathrm{dm}^{-3}\right)$ & 6.96 & 6.57 & 4.10 & 4.66 \\
\hline $\mathrm{T}$ Value $\left(\mathrm{cmol}_{\mathrm{c}} \mathrm{dm}^{-3}\right)$ & 8.56 & 8.72 & 6.68 & 7.85 \\
\hline $\mathrm{V} \%$ & 80.74 & 75.05 & 60.70 & 58.62 \\
\hline Total clay $\left(\mathrm{g} \mathrm{kg}^{-1}\right)$ & 226.60 & 264.25 & 236.40 & 263.17 \\
\hline Total sand $\left(\mathrm{g} \mathrm{kg}^{-1}\right)$ & 611.23 & 589.85 & 544.55 & 630.93 \\
\hline Silt $\left(\mathrm{g} \mathrm{kg}^{-1}\right)$ & 156.35 & 137.80 & 212.58 & 94.67 \\
\hline TOC $\left(\mathrm{g} \mathrm{kg}^{-1}\right)$ & 15.99 & 11.42 & 10.08 & 5.46 \\
\hline $\mathrm{POC}\left(\mathrm{g} \mathrm{kg}^{-1}\right)$ & 3.96 & 1.42 & 7.82 & - \\
\hline MAOC $\left(\mathrm{g} \mathrm{kg}^{-1}\right)$ & 12.03 & 10.01 & 2.27 & - \\
\hline
\end{tabular}

Source: Authors.

\subsection{Statistics, geostatistics and generation of spatial variability maps}

Using PAST 3.5 software, the data obtained were subjected to descriptive statistics and exploratory analysis, in which the values of minimum, maximum, mean, median, skewness and kurtosis, standard deviation (SD) and coefficient of variation (CV\%) were evaluated according to Warrick and Nielsen (1980). The presence of outliers and the normal distribution of the data were checked using the Shapiro-Wilk normality test at 5\% significance level $(\mathrm{p}<0.05)$. Pearson's linear correlation was performed at $5 \%$ significance level $(\mathrm{p}<0.05)$ between soil attributes and SPR values.

Using R Studio 3.5.1 software, a geostatistical study was carried out based on the modeling of semivariograms, in which the semivariance of the data in relation to the distance was verified (Equation 1).

$\hat{\gamma}(h)=\frac{1}{2 N(h)} \sum_{i=1}^{N(h)}\left[Z\left(x_{i}\right)-Z\left(x_{i}+h\right)\right]^{2}$

Where: (h) - estimated semivariance; $\mathrm{N}(\mathrm{h})$ - number of pairs of experimental data separated by vector $\mathrm{h} ; \mathrm{Z}$ - represents the measurement values of soil attributes.

The theoretical semivariograms were tested for exponential, spherical and Gaussian models and were fitted by the Maximum Likelihood method. Cross-validation of the data was performed and the choice of the best model fitted for each variable was determined by the reduced mean error $(\overline{\mathrm{RE}})$ closest to zero, standard deviation of the reduced mean error $\left(\mathrm{S}_{\mathrm{RE}}\right)$ closest to one and the lowest value of the Akaike Information Criterion (AIC) among the models. 
The determination of the fitted semivariogram model allowed estimating the variographic parameters nugget effect, sill and range, and, together with ordinary kriging, made it possible to make spatial inferences about the unsampled sites in the experimental area for the variables under study. Spatial variability maps were generated using ArcGis 10.5 software. The degree of spatial dependence (DSD) of soil attributes was verified based on the assumptions made by Cambardella et al. (1994).

\subsection{Mapping subsoiling at varying depths}

Based on the literature and on the results obtained in the experimental area, a value of SPR was established for soil management purposes. The points that had values equal to or greater than the established SPR value were classified as regions that require decompaction with subsoiling at varying depth. The map of subsoiling at varying depth was performed from ordinary kriging in ArcGis 10.5 software.

\section{Results and Discussion}

The minimum, maximum and mean values of SPR at each depth suggest greater compaction in subsurface, with SPR values ranging from 0.63 $\mathrm{MPa}$ to $15.95 \mathrm{MPa}$ (Table 2).

Table 2. Descriptive statistics of SPR in soil layers under cultivation of 'BRS Princesa' banana.

\begin{tabular}{|c|c|c|c|c|c|c|c|c|}
\hline \multirow{2}{*}{ Variables } & SPR1 & SPR2 & SPR3 & SPR4 & SPR5 & SPR6 & SPR7 & SPR8 \\
\hline & \multicolumn{8}{|c|}{ MPa } \\
\hline Min & 0.63 & 2.12 & 3.00 & 3.00 & 4.00 & 4.00 & 4.00 & 2.50 \\
\hline Max & 4.00 & 8.92 & 14.75 & 15.53 & 15.94 & 15.95 & 14.23 & 14.30 \\
\hline Mean & 2.08 & 4.90 & 7.03 & 7.36 & 8.29 & 8.40 & 7.69 & 7.59 \\
\hline SD & 0.79 & 1.31 & 2.28 & 2.40 & 2.70 & 2.77 & 2.56 & 2.62 \\
\hline Sk & 0.53 & 0.41 & 0.81 & 0.83 & 0.67 & 0.63 & 0.37 & 0.32 \\
\hline Kurt & -0.26 & 0.51 & 1.58 & 1.50 & -0.04 & -0.18 & -0.26 & -0.22 \\
\hline $\mathrm{CV}(\%)$ & 37.86 & 26.75 & 32.44 & 32.60 & 32.63 & 32.97 & 33.30 & 34.49 \\
\hline W Value & $0.97^{\mathrm{ns}}$ & $0.98^{\mathrm{ns}}$ & $0.96 *$ & $0.96^{*}$ & $0.96 *$ & $0.95 *$ & $0.98^{\mathrm{ns}}$ & $0.98^{\mathrm{ns}}$ \\
\hline
\end{tabular}

Min: Minimum; Max: Maximum; SD: Standard deviation; Sk: Skewness; Kurt: Kurtosis; CV (\%): Coefficient of variation; W Value: ShapiroWilk normality test; *significant at 5\% (p<0.05); ns: not significant in the Shapiro-Wilk normality test at 5\%; SPR1 to SPR8: Soil penetration resistance at 0-0.05 (SPR1), 0.05-0.10 (SPR2), 0.10-0.15 (SPR3), 0.15-0.20 (SPR4), 0.20-0.25 (SPR5), 0.25-0.30 (SPR6), 0.30-0.35 (SPR7) and $0.35-0.40$ (SPR8) $\mathrm{m}$.

Source: Authors.

The SPR values obtained in the experimental area were higher when compared to other studies of SPR in banana plantations, values two to three times higher than those of Iori et al. (2012), Miotti et al. (2013) and Batista et al. (2019).

All layers had coefficients of variation classified as medium $(12<\mathrm{CV}<60 \%)$, according to Warrick and Nielsen (1980). Higher CV and lower standard deviation were found at the depth of 0-0.05 $\mathrm{m}$ when compared to the others, indicating lower variances in this layer, although it was mainly affected by soil management. The significance of the Shapiro-Wilk normality test $(\mathrm{p}<0.05)$ together with the values of skewness and kurtosis close to zero of the evaluated depths indicated a tendency to data normality.

Pearson's linear correlations significant at 5\% $(\mathrm{p}<0.05)$ of soil attributes with SPR suggest that SPR and, indirectly, soil compaction, may be restricting the access of banana plants to soil nutrients. The negative correlation of SPR with $\mathrm{Mg}^{+2} \mathrm{values}$ indicates damage to the availability of this nutrient in the soil for absorption by banana roots due to the increase in SPR. 
The positive correlations between SPR and P indicate that the greater soil compaction in subsurface caused higher P adsorption on the surface of soil colloids and led to a reduction in the diffusive flow of ions in the soil solution (Ribeiro et al., 2010) with the roots of banana trees.

The negative correlations observed in subsurface between the soil particle-size fractions and the SPR suggest that the finest fractions of the soil (total clay and silt) together with MAOC were responsible for the greater capacity of water storage and retention in the soil and, consequently, reduction of SPR.

At all depths there was a predominance of the medium texture (Figure 3), and these soils are the most recommended for banana cultivation (Aguirre et al., 2012).

Figure 3. Textural classes at 0-0.05 m (a), 0.05-0.10 m (b), 0.10-0.20 m (c) and 0.20-0.40 m (d) according to Santos et al. (2015).

a)

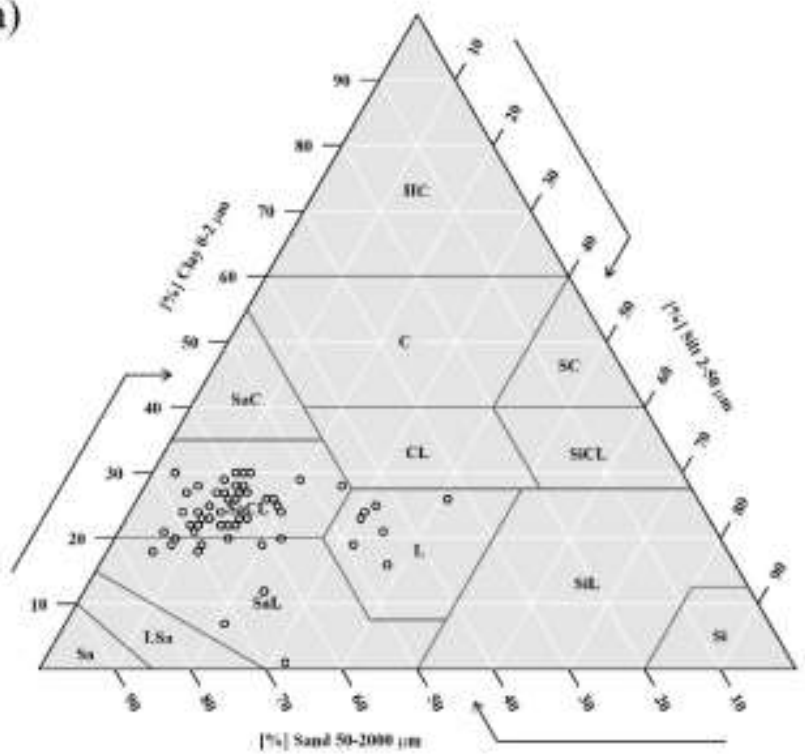

c)

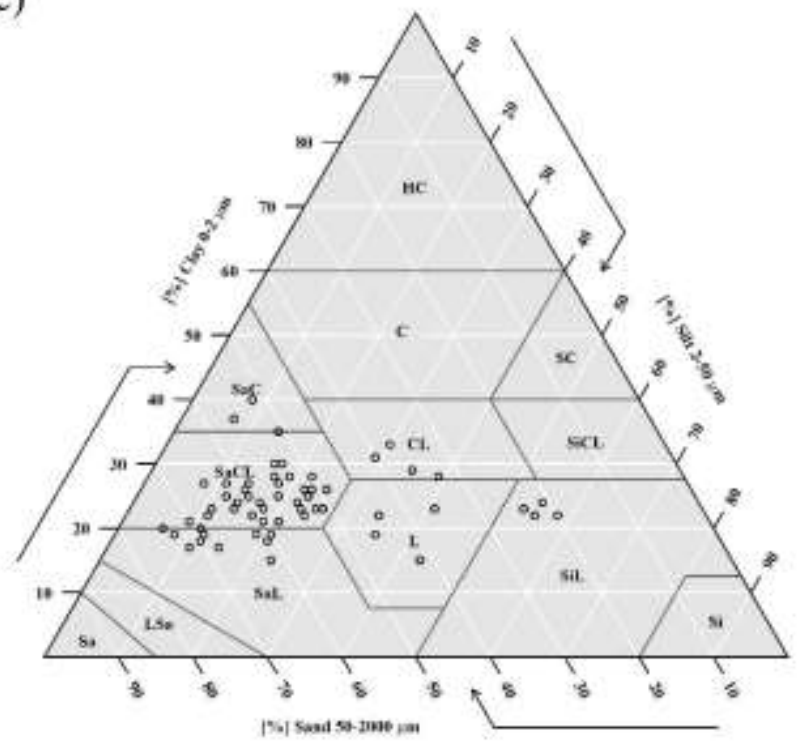

b)

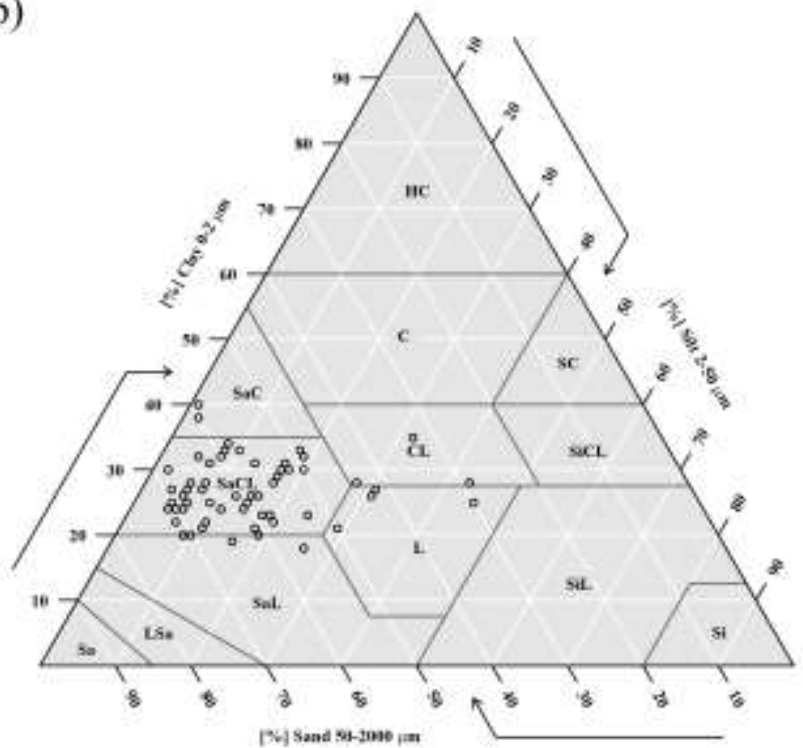

d)

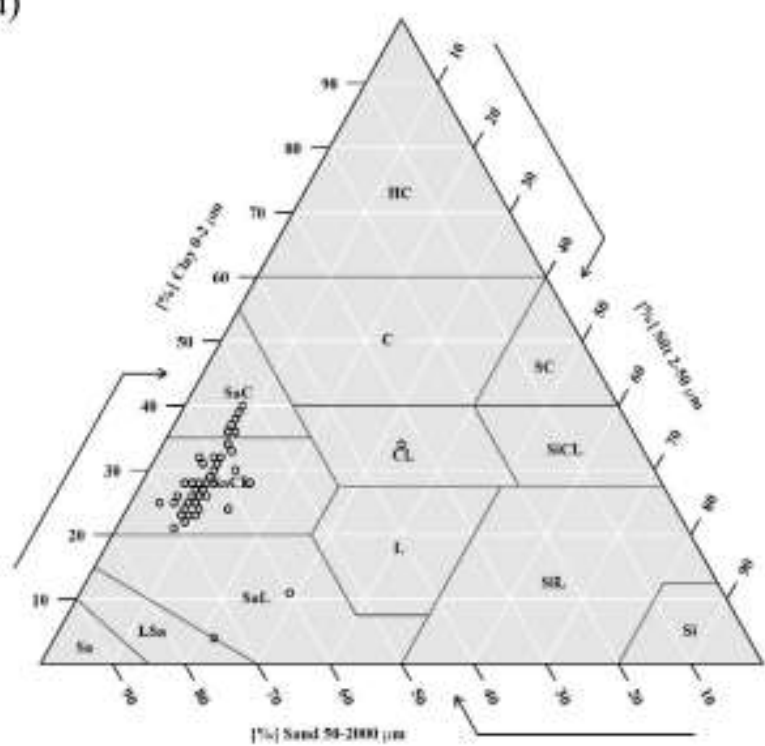

Sa: Sand; LSa: Loamy sand; SaL: Sandy loam; L: Loam; SaCL: Sandy clay loam; SiL: Silty loam; Si: Silt; SaC: Sandy clay; CL: Clay loam; SiCL: Silty clay loam; C: Clay; SC: Silty clay; HC: Heavy clay.

Source: Authors.

Soils with sandier texture (in surface, Figure $3 \mathrm{a}-\mathrm{c}$ ), which tend to form aggregates with weak degree of aggregation, 
showed increase of clay fraction in subsurface due to translocation, corroborating negative correlations with SPR. That is, the higher the clay fraction content, the lower the SPR values, demonstrating that the high SPR observed occurs due to the managements carried out in the banana plantation.

The higher mean contents of TOC and MAOC in the surface layer when compared to the other depths (Table 1) and the negative correlation of SPR with MAOC at 0.10-0.20 m indicate that these fractions are contributing to lower values of SPR, because SOM is a conditioner of soil structure, aggregate stability, porosity and density (Melo \& Alleoni, 2019), which indirectly influences SPR. In general, the significant correlations between the values of SPR and soil attributes suggest effects on organomineral interactions and, consequently, losses for banana plants, especially in the $0.10-0.20$ m layer.

In the variographic study, the models for SPR in the different layers were mostly fitted by the spherical model, followed by the Gaussian model (Table 3).

Table 3. Parameters obtained through the modeling of semivariograms from the SPR values in cultivation of 'BRS Princesa' banana.

\begin{tabular}{ccccccccc}
\hline SPR $(\mathrm{MPa})$ & Model & $\mathrm{C}_{0}$ & $\mathrm{C}$ & $\mathrm{A}(\mathrm{m})$ & $\mathrm{DSD}$ & $\mathrm{RE}$ & $\mathrm{S}$ RE & AIC \\
\hline $0.00-0.05 \mathrm{~m}$ & $\mathrm{Sph}$ & 0.000 & 0.615 & 9.1 & Strong & 0.0092 & 1.0243 & 144.991 \\
$0.05-0.10 \mathrm{~m}$ & $\mathrm{Sph}$ & 0.000 & 1.703 & 8.7 & Strong & 0.0122 & 1.0408 & 207.227 \\
$0.10-0.15 \mathrm{~m}$ & $\mathrm{Sph}$ & 0.000 & 5.153 & 11.8 & Strong & 0.0287 & 1.0890 & 264.522 \\
$0.15-0.20 \mathrm{~m}$ & $\mathrm{Sph}$ & 0.000 & 5.648 & 12.0 & Strong & 0.0235 & 1.0676 & 269.326 \\
$0.20-0.25 \mathrm{~m}$ & $\mathrm{Sph}$ & 1.823 & 7.544 & 13.5 & Strong & 0.0071 & 1.1088 & 289.713 \\
$0.25-0.30 \mathrm{~m}$ & $\mathrm{Gau}$ & 3.832 & 7.852 & 7.1 & Moderate & 0.0045 & 1.1077 & 294.617 \\
$0.30-0.35 \mathrm{~m}$ & $\mathrm{Sph}$ & 2.739 & 6.481 & 13.6 & Moderate & -0.0004 & 1.1641 & 284.759 \\
$0.35-0.40 \mathrm{~m}$ & $\mathrm{Gau}$ & 4.262 & 6.776 & 8.6 & Moderate & 0.0069 & 1.1684 & 286.949 \\
\hline
\end{tabular}

Sph: spherical; Exp: exponential; Gau: Gaussian; $\mathrm{C}_{0}$ : nugget effect; C: sill; A: range; DSD: degree of spatial dependence; $\overline{\mathrm{RE}}$ : reduced mean error; $\mathrm{S}_{\mathrm{RE}}$ : standard deviation of reduced mean error; AIC: Akaike information criterion.

Source: Authors.

All variables showed a strong degree of spatial dependence according to the classification of Cambardella et al. (1994), except SPR in the 0.25-0.30, 0.30-0.35 $\mathrm{m}$ and 0.35-0.40 $\mathrm{m}$ layers, which had DSD values classified as moderate. The range values varied from $7.1 \mathrm{~m}(0.25-0.30 \mathrm{~m})$ to $13.6 \mathrm{~m}(0.30-0.35 \mathrm{~m})$, indicating the greatest distances at which spatial correlations between the samples were observed (Figure 4). 
Figure 4. Spatial distribution of SPR at different soil depths under 'BRS Princesa' banana cultivation. SPR at 0-0.05 (a), 0.050.10 (b), 0.10-0.15 (c), 0.15-0.20 (d), 0.20-0.25 (e), 0.25-0.30 (f), 0.30-0.35 (g) and 0.35-0.40 (h) m.
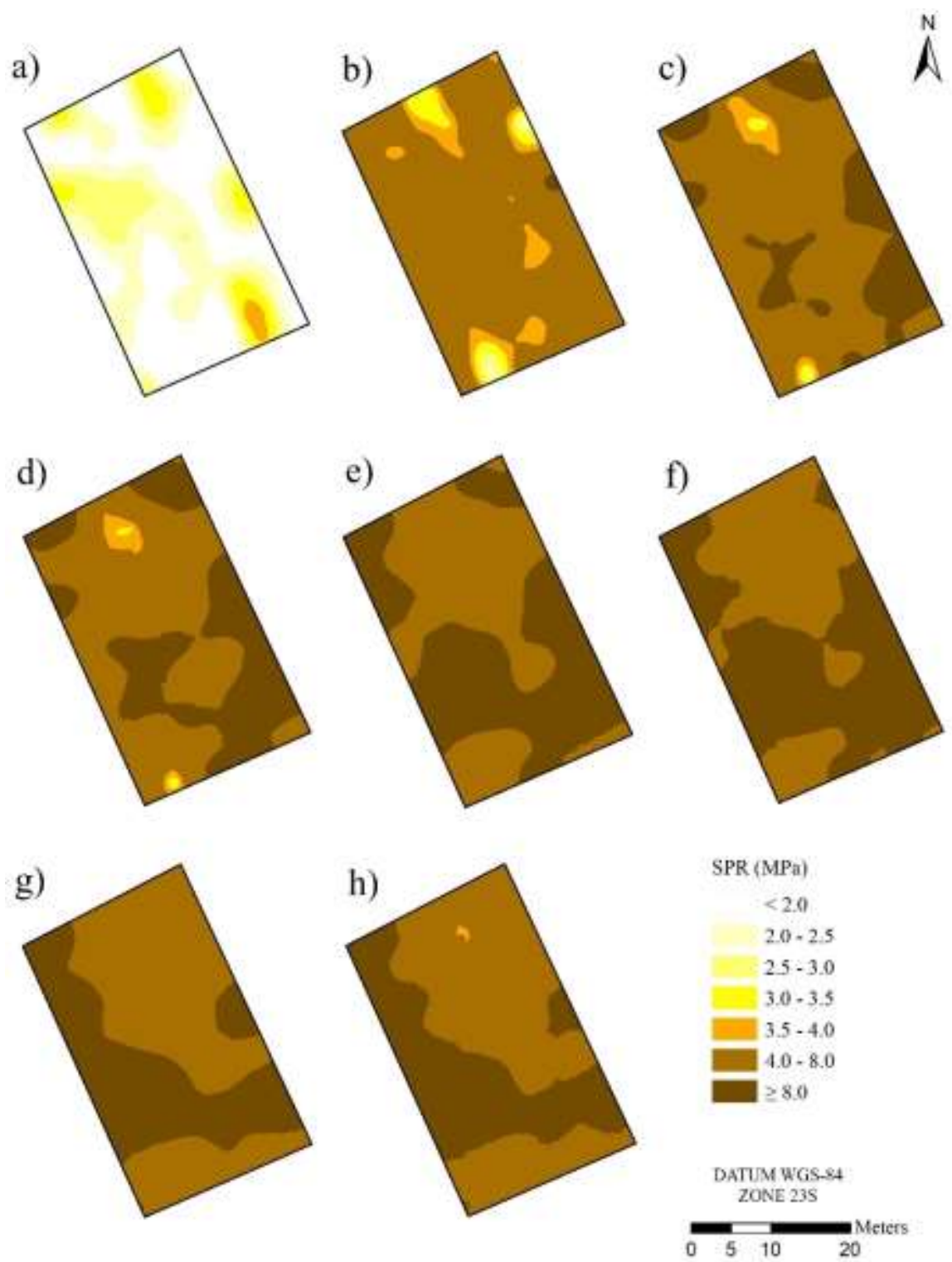

Source: Authors.

The surface layer (Figure 4a) had lower values of SPR, which may be due to the plant residues from the thinning and defoliation of banana plantations, increasing the organic matter. Such increase in surface is one of the main responsible for minimizing the effects of the pressure generated on the soil (Tiecher, 2016).

There is an increase in SPR in subsurface, which is intensified in the layers of 0.20-0.25 $\mathrm{m}$ (Figure 4e) and 0.25-0.30 $\mathrm{m}$ (Figure 4f). It is important to mention that $30 \%$ of the banana roots are located in the $0-0.10 \mathrm{~m}$ layer and about $82 \%$ in the $0-0.50$ m layer, extending horizontally up to 1 to $2 \mathrm{~m}$ and possibly reaching up to $5 \mathrm{~m}$ (Borges \& Souza., 2004), so SPR values can be influenced by the large amount of roots present in the study area (Tiecher, 2016).

An analysis of Figures $4 \mathrm{~g}$ and $4 \mathrm{~h}$ showed that SPR values are decreasing and dissipating in regions of the $0.30-0.35 \mathrm{~m}$ and 0.35-0.40 m layers, respectively, but still have regions with SPR values of 14.94 MPa, considered very high. The high SPR values indicate that these soils have compaction levels that may be limiting the development of banana crop. Factors such as soil 
pedogenesis may be related to the observation of these values, since the accumulation of fine sand and illuviated clay in subsurface in the Ultisol (Argissolo), especially in $0.20-0.40 \mathrm{~m}$ in the banana plantation, induce a better adjustment of these particles, reducing the porous space and, consequently, influencing soil compaction.

The useful life of the bananal it is almost seven years old, with a marked decrease in yield in the last two years. Thus, from the history and the variables investigated it is possible to understand the behavior and low yield of the experimental area. The suspension of the irrigation system in the banana area, as well as the occurrence of weeds, may also be factors that contribute to the low yield potential shown by the banana plantation.

As reference for use in penetrometry, Silveira et al. (2010) suggest as critical limits the SPR values between 2.0 and 2.5 MPa for most plants, as well as other authors suggest classifications of SPR (Soil Survey Staff, 1993; Beutler et al., 2001). SPR values in the 0.10-0.20 layer were the most limiting in soil solution interactions (correlations significant at 5\%) and, when observing the spatial variability maps of these layers (Figures 4c and 4d), it was noticed that the regions with highest SPR intensified and increased in the same places up to the 0.20-0.25 m layer (Figure 4e), and more compacted regions were observed at this depth.

Based on the experimental conditions and considering the critical limits suggested by the various authors, it was possible to affirm that the SPR values above 8.0 MPa were high enough for recommending localized managements to reduce soil penetration resistance in the banana plantation. Thus, mechanized soil tillage can be performed and soil decompaction by localized subsoiling at varying depth is indicated for a new banana plantation, considering that compaction was not negative throughout the experimental area (Figure 5).

Figure 5. Spatial variability map of SPR greater than or equal to $8.0 \mathrm{MPa}$ with indication of soil decompaction by subsoiling at varying depth.

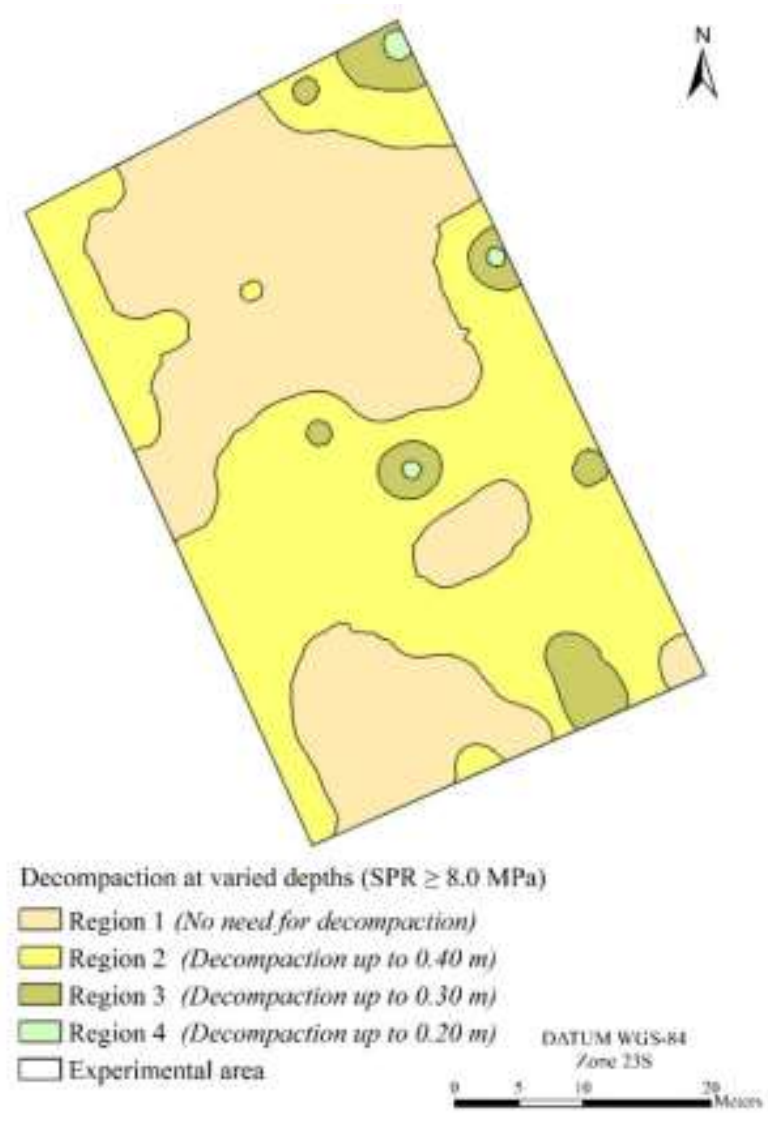

Source: Authors. 
Among the sampled sites, $40 \%$ of the points did not have in subsurface SPR values higher than or equal to 8.0 MPa and, when performing the estimation of the unsampled sites, it was possible to infer that $46.7 \%$ of the total area of the banana plantation does not require decompaction (Region 1). Decompaction by subsoiling is indicated at three different depths: 0 to 0.40 $\mathrm{m}, 0$ to $0.30 \mathrm{~m}$ and 0 to $0.20 \mathrm{~m}$, characterized by regions 2,3 and 4, respectively. This type of localized management is extremely important, since it is possible to mobilize only compacted layers, maintaining their structure and organic matter protected within aggregates and avoiding excessive disaggregation (Tiecher, 2016; Cortez et al., 2020).

Regions 2, 3 and 4 represent $48 \%, 4.9 \%$ and $0.4 \%$ of the total area of the banana plantation, respectively, indicating that decompaction by subsoiling at varying depth and in specific regions will represent a lower energy expenditure, fuel consumption and carbon emission to the atmosphere, as well as greater operational capacity when this practice is compared to the conventional method. This pattern has been observed by Machado et al. (2015) and Cortez et al. (2020), who verified a reduction in expenses with the use of localized subsoiling at varying depth.

\section{Conclusion}

The SPR values at the evaluated depths suggest greater compaction in subsurface, indicating the beneficial effects on soil surface promoted by soil organic matter in the banana plantation. The correlations between SPR and soil attributes suggest effects on organo-mineral interactions and, consequently, losses for banana plants, especially in the 0.10-0.20 m layer.

Mechanized soil tillage with localized subsoiling at varying depth was indicated for SPR values above 8.0 MPa. It was found that $46.7 \%$ of the total area of the banana plantation does not need to be decompacted, indicating that subsoiling at varying depth and in specific regions will represent lower energy expenditure and fuel consumption and lower carbon emission to the atmosphere compared to performing this practice by the conventional method.

\section{Acknowledgments}

This work was supported by Coordenação de Aperfeiçoamento de Pessoal de Nível Superior - Brasil (CAPES) - Finance Code 001 and Federal Rural University of Rio de Janeiro.

\section{References}

Abreu, R. L. (2021). Map locator of Rio de Janeiro's Seropédica city. https://commons.wikimedia.org/wiki/File:RiodeJaneiro_Municip_Seropedica.svg

Aguirre, S. E., Piraneque, N. V., \& Menjivar, J. C. (2012). Relación entre las propiedades edafoclimáticas y la incidencia de Sigatoka negra (Mycosphaerella fijiensis Morelet) en la zona bananera del Magdalena-Colombia. Revista de investigación agraria y ambiental, 3 (2), 13-25.

Batista, P. H. D., Montenegro, A. A. A., Almeida, G. L. P., Tavares, U. E., \& Rodrigues, R. A. S. (2019). Variabilidade espacial da resistência à penetração e teor de água em Neossolo cultivado com banana no agreste pernambucano. Revista Engenharia na Agricultura, 27 (1), 54-60. https://doi.org/10.13083/reveng.v27i1.881.

Beutler, A. N., Silva, M. L. N., Curi, N., Ferreira, M. M., Cruz, J. C., \& Pereira Filho, I. A. (2001). Resistência à penetração e permeabilidade de Latossolo Vermelho distrófico típico sob sistemas de manejo na região dos cerrados. Revista Brasileira de Ciência do Solo, 25 (1), 167-177. http://dx.doi.org/10.1590/S0100-06832001000100018.

Borges, A. L. \& Cordeiro, Z. J. M. (2021). Cultivo de bananeiras tipo maçã - 'BRS Princesa' e 'BRS Tropical'. Cruz das Almas, BA: Embrapa Mandioca e Fruticultura, Sistema de $\quad$ Produção, $\quad$ https://www.spo.cnptia.embrapa.br/conteudo?p_p_id=conteudoportlet_WAR _sistemasdeproducaolf6_1ga1ceportlet\&p_p_lifecycle=0\&p_p_state=normal\&p_p_mode=view\&p_p_col_id=column-3\&p_p_col_count=1\&p_r_p_76293187_sistemaProducaoId=9212\&p_r_p_-996514994_topicoId=10671

Borges, A. L. \& Souza, L. S. (2004). $O$ cultivo da bananeira. Cruz das Almas: Embrapa Mandioca e Fruticultura. 279p. https://www.infoteca.cnptia.embrapa.br/infoteca/bitstream/doc/1005043/1/LivroBanana.pdf.

Cambardella, C. A., Moorman, T. B., Novak, J. M., Parkin, T. B., Karlen, D. L., Turco, R. F., \& Konopka, A. E. (1994). Field-scale variability of soil properties in central Iowa soils. Soil Science Society of America Journal, 58 (5), 1501-1511. https://doi.org/10.2136/sssaj1994.03615995005800050033x.

Cambardella, C. A. \& Elliott, E. T. (1992). Particulate soil organic-matter changes across a grassland cultivation sequence. Soil Science Society of America Journal, 56 (3), 777-783. https://doi.org/10.2136/sssaj1992.03615995005600030017x. 
Cortez, L. A., Marques Júnior, J., Peluco, R. G., Siqueira, D. S., Siansi, F. L., Barbosa, R. S., Furlani, C. E. A., Camargo, L. A., Silva, L. S., \& Gomes, R. P. (2020). Subsoiling of an oxisol at fixed and varying depth in áreas under sugarcane. Precision Agriculture, 21, 1351-1365. https://doi.org/10.1007/s11119-02009724-4.

Food And Agriculture Organization Of The United Nations - FAO. (2021). Markets and trade: Bananas. http://www.fao.org/economic/est/estcommodities/bananas/en/.

Food And Agriculture Organization Of The United Nations - FAO. (2020). Medium-term Outlook: Prospects for global production and trade in bananas and tropical fruits 2019 to 2028. http://www.fao.org/3/ca7568en/ca7568en.pdf.

Food And Agriculture Organization Of The United Nations - FAO. (2018). Food Outlook: Biannual Report on Global Food Markets - November 2018. http://www.fao.org/3/CA2320EN/ca2320en.pdf.

Google. (2021). Google Earth. https://www.google.com.br/intl/pt-BR/earth/.

Instituto Brasileiro de Geografia e Estatísticas - IBGE. (2019). Indicadores IBGE - Levantamento Sistemático da Produção Agrícola Estatística da Produção Agrícola/dezembro 2019. https://biblioteca.ibge.gov.br/visualizacao/periodicos/2415/epag_2019_dez.pdf>.

Instituto Nacional de Meteorologia - INMET. (2020). INMET Tempo. https://tempo.inmet.gov.br/GraficosDiarios/A601.

Iori, P., Dias Júnior, M. S., \& Silva, R. B. (2012). Resistência do solo à penetração e ao cisalhamento em diversos usos do solo em áreas de preservação permanente. Bioscience Journal, 28 (Supplement 1), 185-195.

Lanza, T. R., Machado, A. F. L., \& Martelleto, L. A. P. (2017). Effect of planting densities of "BRS Princess" banana tree in the suppression of weeds. Planta daninha, 35 (e017162958). https://doi.org/10.1590/s0100-83582017350100054.

Machado, T. M., Lanças, K. P., Fiorese, D. A., Fernandes, B. B., \& Testa, J. V. P. (2015). Estimativa de gasto energético da operação de subsolagem em profundidades. Revista Brasileira de Engenharia Agrícola e Ambiental, 19 (11), 1121-1125. https://doi.org/10.1590/1807-1929/agriambi.v19n11p1121-1125.

Melo, V. F. \& Alleoni, L. R. F. (2019). Química e Mineralogia do Solo - Conceitos Básicos e Aplicações. Viçosa, MG: Sociedade Brasileira de Ciência do Solo. 1381 p.

Miotti, A. A., Costa, M. C. G., Ferreira, T. O., \& Romero, R. E. (2013). Profundidade e atributos físicos do solo e seus impactos nas raízes de bananeiras. Revista Brasileira de Fruticultura, 35 (2), 536-545. http://dx.doi.org/10.1590/S0100-29452013000200024.

Olivares, B. O., Araya-Alman, M., Acevedo-Opazo, C., Rey, J. C., Cañete-Salinas, P., Kurina, F. G., Balzarini, M., Lobo, D., Navas-Cortés, J. A., Landa, B. B., \& Gómez, J. A. (2020). Relationship Between Soil Properties and Banana Productivity in the Two Main Cultivation Areas in Venezuela. Journal of Soil Science and Plant Nutrition, 20, 2512-2524. https://doi.org/10.1007/s42729-020-00317-8.

Ribeiro, M. A. V., Novais, R. F., Faquin, V., Ferreira, M. M., Furtini Neto, A. E., Lima, J. M., \& Villani, E. M. A. (2010). Resposta da soja e do eucalipto ao aumento da densidade do solo e a doses de fósforo. Revista Brasileira de Ciência do Solo, 34 (4), 1157-1164. http://dx.doi.org/10.1590/S010006832010000400015

Santos, H. G., Jacomine, P. K. T., Anjos, L. H. C., Oliveira, V. A., Lumbreras, J. F., Coelho, M. R., Almeida, J. A., Araujo Filho, J. C., Oliveira, J. B., \& Cunha, T. J. F. (2018). Sistema Brasileiro de Classificação de Solos. Brasília, DF: Embrapa. 356p.

Santos, R. D., Santos, H. G., Ker, J. C., Anjos, L. H. C., \& Shimizu, S. H. (2015). Manual de descrição e coleta de solo no campo. Viçosa, MG: Sociedade Brasileira de Ciência do solo. 101p.

Silveira, D. C., Melo Filho, J. F., Sacramento, J. A. A. S., \& Silveira, E. C. P. (2010). Relação umidade versus resistência à penetração para um Argissolo Amarelo distrocoeso no recôncavo da Bahia. Revista Brasileira de Ciência do Solo, 34 (3), 659-667. http://dx.doi.org/10.1590/S0100-06832010000300007.

Soil Survey Staff. (1993). Soil Survey Manual. Washington: USDA-SCS. U.S. Gov. Print. Office. 437p. (Handbook, 18).

Stolf, R., Fernandes, J., \& Furlani Neto, V. L. (1983). Recomendação para uso do penetrômetro de impacto, modelo IAA/Planalsucar - Stolf. São Paulo: MIC/IAA/PNMCA - Planalsucar. 8p. (Série Penetrômetro de Impacto - Boletim, 1).

Teixeira, P. C., Donagemma, G. K., Fontana, A., \& Teixeira, W. G. (2017). Manual de métodos de análise de solo. Brasília, DF: Embrapa. 573p.

Tiecher, T. (Org.). (2016). Manejo e conservação do solo e da água em pequenas propriedades rurais no Sul do Brasil: Práticas alternativas de manejo visando a conservação do solo e da água. Porto Alegre: UFGRS. 186p.

Villarreal-Núñez, J., Pla-Sentis, I., Agudo-Martínez, L., Villaláz-Perez, J., Rosales, F., \& Pocasangre, L. (2013). Soil quality indexes in areas cultivated with banana in Panama. Agronomía Mesoamericana, 24 (2), 301-315. http://dx.doi.org/10.15517/AM.V24I2.12530.

Warrick, A. W. \& Nielsen, D. R. (1980). Spatial variability of soil physical properties in the field. In: HILLEL, D. (Ed.). Applications of soil physics. New York: Academic press. Cap.2, p.319-344.

Yeomans, J. C. \& Bremner, J. M. (1988). A rapid and precise method for routine determination of organic carbon in soil. Communications in Soil Science and Plant Analysis, 19 (13), 1467-1476. 